\title{
PERAN MPK PAI DALAM MEMBANGUN KARAKTER MAHASISWA STIESIA SURABAYA
}

\author{
Dewi Mutmainnah \\ Sekolah Tinggi Ilmu Ekonomi Indonesia (STIESIA) Surabaya - Indonesia \\ Email: dewimutmainnah@stiesia.ac.id
}

\begin{abstract}
This study aims to determine and understand the role of the Personality Development Course (MPK) of Islamic Religious Education (PAI) and its effectiveness in building the character of STIESIA Surabaya students. This research is a qualitative research using data analysis of Spradley model and taking the location of research in the STIESIA Surabaya campus. The result of this study found that character building through the courses of Islamic Religion in STIESIA was pursued with 3 strategies, namely: (1) Moral Knowing, was the first stage carried out by Islamic Religious Education lecturers and oriented to mastering knowledge of moral values noble; (2) Moral Loving, the stage where after students are able to master knowledge of noble moral values, the lecturers touches the emotional aspects of the soul and heart of students so that they love these nobel moral values and "need" to do it in their daily lives; and then (3) Moral Doing, is the peak stage which is said to be a sign of success in building the character of students that is practicing noble character in real life everyday. Form the observations and interviews, the courses on Islamic Religious Education at STIESIA managed to build the character of students for the better.
\end{abstract}

\begin{abstract}
ABSTRAK
Penelitian ini bertujuan untuk mengetahui dan memahami peran Mata Kuliah Pengembangan Kepribadian (MPK) Pendidikan Agama Islam (PAI) serta efektivitasnya dalam membangun karakter mahasiswa STIESIA Surabaya. Penelitian ini adalah penelitian kualitatif dengan menggunakan analisis data model Spradley dan mengambil lokasi penelitian di lingkungan kampus STIESIA Surabaya. Hasil penelitian ini menemukan bahwa Pembangunan karakter melalui mata kuliah Pendidikan Agama Islam di STIESIA ditempuh dengan 3 strategi yaitu : (1) Moral Knowing/ Learning to Know, merupakan tahap pertama yang dilakukan yang berorientasi kepada penguasaan pengetahuan tentang nilai nilai akhlak mulia; (2) Moral Loving, tahapan dimana dosen menyentuh aspek emosional jiwa dan hati mahasiswa agar mencintai nilai-nilai akhlak mulia tersebut dan "butuh" untuk melakukannya dalam kehidupan sehari-hari; dan (3) Moral Doing, adalah tahapan puncak dalam membangun karakter mahasiswa yaitu mempraktikkan akhlak mulia dalam kehidupan sehari-hari. Berdasarkan pengamatan dan wawancara Mata kuliah Pendidikan agama Islam di STIESIA berhasil membangun karakter mahasiswa menjadi lebih baik.
\end{abstract}

Key words : Mata kuliah Pengembangan Kepribadian Pendidikan Agama Islam (MPK PAI), Pembangunan Karakter, STIESIA. 


\section{A. PENDAHULUAN}

Keberhasilan suatu bangsa dalam memperoleh tujuannya tidak hanya dapat ditentukan oleh melimpah ruahnya sumber daya alam seperti yang dimiliki Indonesia, tetapi juga sangat ditentukan oleh kualitas sumber daya manusianya. Dan satu hal untuk meningkatkan dan membangun kualitas sumber daya manusia adalah melalui pendidikan.

Socrates, filusup Yunani, mengatakan bahwa tujuan utama dari pendidikan adalah untuk membuat seseorang menjadi good dan smart. Dalam Islam sendiri, Nabi Muhammad saw, selaku nabi terakhir juga menegaskan bahwa misi utamanya dalam mendidik manusia adalah untuk mengupayakan pembentukan karakter yang baik (good character= akhlakul karimah). Selanjutnya puluhan abad setelahnya, para tokoh pendidikan barat seperti Klipatrick, Lickona, Brooks dan Goble menyuarakan hal yang sama sebagaimana Socrates dan Muhammad saw, yaitu moral, akhlak atau karakter adalah tujuan yang tidak terhindarkan dari dunia pendidikan. Marthin Luther King pun mengatakan "Intelligence plus character, that is the true aim of education". Kecerdasan plus karakter, itulah tujuan yang benar dari pendidikan. ${ }^{1}$ Dalam alquran dikatakan ilmu plus ketaqwaan adalah hal yang harus dimiliki oleh seseorang sehingga bisa disebut ulul albab.

Indonesia adalah negara yang berlandaskan kepada Pancasila dengan sila pertama yang berbunyi "Ketuhanan Yang Maha Esa" menegaskan bahwa religiusitas menjadi inti dari kehidupan masyarakatnya dalam berbangsa dan bernegara. Hal ini juga didukung dengan Undang-undang No. 20 tahun 2003 yang menegaskan bahawa pendidikan nasional berfungsi mengembangkan kemampuan dan membentuk watak serta peradaban bangsa yang bermartabat dalam rangka mencerdaskan kehidupan bangsa. Adapun tujuan pendidikan nasional adalah untuk berkembangnya potensi peserta didik agar menjadi manusia yang beriman dan bertakwa kepada Tuhan yang Maha Esa, berakhlak mulia, sehat, berilmu, cakap, kreatif, mandiri, dan menjadi warga negara yang demokratis serta bertanggung jawab. ${ }^{2}$

Pendidikan Agama memiliki peranan penting dalam mewujudkan tujuan pendidikan nasional tersebut di atas. Oleh karena itu Undang-undang No. 20 tahun 2003 selanjutnya pada pasal 37 ayat (1) a dan (2) a menyatakan bahawa isi kurikulum semua jenjang pendidikan harus memasukkan Pendidikan Agama. ${ }^{3}$ Hal ini dipertegas lagi dalam Peraturan Pemerintah No. 19 tahun 2005 tentang Standar Nasional Pendidikan dimana dalam struktur mata kuliah di perguruan tinggi, khususnya perguruan tinggi umum (PTU), Pendidikan Agama dimasukkan dalam kelompok mata kuliah dasar umum

\footnotetext{
${ }^{1}$ Majid, Abdul dan Dian Andayani. Pendidikan Karakter Perspektif Islam, (Bandung: PT. Remaja Rosdakarya, 2017), Hlm. 30.

2 Undang-Undang No. 20 Tahun 2003 tentang Sistem Pendidikan Nasional

3 Undang-Undang No. 20 Tahun 2003 tentang Sistem Pendidikan Nasional
} 
(MKDU) ${ }^{4}$ yang mulai tahun 2000 sampai saat ini berkembang menjadi mata kuliah pengembangan kepribadian (MPK). Pendidikan Agama, dalam hal ini Pendidikan Agama Islam, adalah mata kuliah dasar wajib yang harus ditempuh oleh setiap mahasiswa, diharapkan mampu menopang pembangunan karakter dan profesionalitas nya sebagai manusia yang tidak hanya ahli dan cakap dalam bidang akademik sesuai kompetensi keilmuan tetapi juga berakhlak mulia.

Adapun tujuan dari penelitian ini adalah untuk mengetahui dan menganalisa peran MPK PAI dalam membangun karakter mahasiswa STIESIA Surabaya, dan menganalisa efektivitas MPK PAI dalam membangun karakter mahasiswa STIESIA Surabaya.

\section{B. KERANGKA TEORI}

\section{1) Pendidikan Karakter}

Karakter dalam pandangan Ryan dan Bohlin, mempunyai tiga pilar pokok, yakni mengetahui dan memahami kebaikan (knowing the good), mencintai kebaikan (loving the good), dan melakukan kebaikan (doing the good). Pada pendidikan karakter, kebaikan adalah sering kali dihimpun dalam kumpulan sifat-sifat baik. Oleh karena itu, pendidikan karakter adalah suatu usaha untuk membimbing prilaku manusia mengarah ke standart-standart umum/ baku. ${ }^{5}$ Usaha ini juga memberikan ruang untuk mengapresiasi persepsi dan nilai-nilai pribadi yaang ditampilkan. Fokus pendidikan karakter adalah terletak dalam tujuan-tujuan etika, tetapi praktiknya mencakup penguatan kecakapan-kecakapan penting yaang meliputi perkembangan sosial individu.

Pendidikan karakter menurut Ratna Megawangi adalah sebuah usaha untuk mendidik anak-anak agar dapat mengambil keputusan dengan bijak dan mempraktikkannya dalam kehidupan sehari-hari, sehingga mereka dapat memberikan kontribusi yang positif kepada lingkungannya. ${ }^{6}$ Fakry Gaffar juga memberikan definisi lain dari pendidikan karakter yaitu sebuah proses transformasi nilai-nilai kehidupan untuk ditumbuhkembangkan dalam kepribadian seseorang sehingga menjadi satu dalam perilaku kehidupan orang itu. ${ }^{7}$ Dalam definisi tersebut, ada tiga ide pikiran penting yaitu (1) proses transformasi nilai-nilai, (2) ditumbuhkembangkan dalam kepribadian, dan (3) menjadi satu dalam perilaku.

\footnotetext{
${ }^{4}$ Peraturan Pemerintah No. 19 tahun 2005 tentang Standar Nasional Pendidikan

5 Majid, Abdul dan Dian Andayani. Pendidikan Karakter Perspektif Islam, (Bandung: PT. Remaja Rosdakarya, 2017), Hlm. 11.

${ }^{6}$ Kesuma, Dharma et al. Pendidikan Karakter, Kajian Teori dan Praktik di Sekolah. (Bandung: PT. Remaja Rosdakarya. 2013), Hlm. 5.

${ }^{7}$ Kesuma, Dharma et al. Pendidikan Karakter.. Hlm.5
} 
Akhir-akhir ini, Pendidikan Karakter menjadi isu utama dalam pendidikan di Indonesia dan diyakini sebagai sebuah proses yang dilakukan untuk membentuk akhlak warga bangsa, dimana salah satunya dikarenakan keprihatinan akan krisis moral yang melanda warga bangsa Indonesia seperti disebutkan sebelumnya. Dalam Undang-undang RI Nomer 20 tahun 2003 Bab 1 Pasal 1 ayat (1) disebutkan bahwa "Pendidikan adalah usaha sadar dan terencana untuk mewujudkan suasana belajar dan proses pembelajaran agar peserta didik secara aktif mengembangkan potensi dirinya untuk memiliki kekuatan spiritual keagamaan, pengendalian diri, kepribadian, kecerdasan, akhlak mulia, serta keterampilan yang diperlukan dirinya, masyarakat bangsa, dan Negara". Ini menunjukkan bahwa tujuan dari pendidikan tidak hanya membentuk manusia Indonesia yang cerdas secara kognitif, tetapi juga berkepribadian atau berkarakter, sehingga nantinya akan lahir generasi bangsa yang tumbuh berkembang dalam menjalani kehidupannya dengan terus berpegang teguh pada nilai-nilai luhur bangsa dan agama.

\section{2) Pendidikan Agama Islam}

Pendidikan Agama Islam merupakan salah satu pilar pendidikan karakter yang utama. Karakter yang baik akan menjadi maksimal dalam pertumbuhan dan perkembangannya jika didasari dengan keberagamaan yang baik pada individu. Karena itulah keberadaan pendidikan agama Islam menjadi sangat penting dalam sistem pendidikan nasional di Indonesia. Pendidikan agama Islam merupakan sarana tranformasi pengetahuan dalam aspek keagamaan (aspek kognitif), sebagai sarana tranformasi norma serta nilai moral untuk membentuk sikap (aspek afektif), yang berperan dalam mengendalikan perilaku (aspek psikomotorik) sehingga tercipta kepribadian manusia seutuhnya.

Dengan adanya Pendidikan Agama Islam di kurikulum semua jenjang pendidikan diharapkan mampu menghasilkan manusia yang selalu berupaya menyempurnakan iman, takwa, dan berkhlak mulia. Akhlak mulia mencakup etika, budi pekerti, atau moral sebagai perwujudan dari pendidikan. ${ }^{8}$ Manusia sebagaimana di atas dituntut bermental dan berkepribadian handal dan tangguh daalam menghadapi kesulitan, hambatan, perubahan, dan tantangan yang muncul daalam perrgaulan masyarakat, baik daalam lingkup lokal, nasional, maupun global.

\section{3) MPK PAI dan Pembangunan Karakter}

\footnotetext{
8 Permendiknas No. 22 tahun 2006. Tentang Standar Isi Untuk Satuan Pendidikan Tingkat Dasar dan Menengah. Hlm. 2
} 
Dalam Undang- Undang RI Nomor 20 tahun 2003 Bab 1 Pasal 1 ayat (1) dijelaskan bahwa yang dimaksud dengan pendidikan adalah: "Pendididikan adalah usaha sadar dan terencana untuk mewujudkan suasana belajar dan proses pembelajaran agar peserta didik secara aktif mengembangkan potensi dirinya untuk memiliki kekuatan spiritual kegamaan, pengendalian diri, kepribadian, kecerdasan, akhlak mulia, serta keterampilan yang diperlukan dirinya, masyarakat bangsa, dan negara". Dan dalam Bab II Pasal 3 disebutkan: "Pendidikan nasional berfungsi mengembangkan kemampuan dan membentuk watak serta peradaban bangsa yang bermartabat dalam rangka mencerdaskan kehidupan bangsa, bertujuan untuk berkembangnya potensi peserta didik agar menjadi manusia yang beriman dan bertakwa kepada Tuhan Yang Maha Esa, berakhlak mulia, sehat, berilmu, cakap, kreatif, mandiri, dan menjadi warga negara yang demokratis serta bertanggung jawab". Memahami amanah yang tertuang dalam Undang-undang ini menunjukkan kepada kita bahwa pendidikan tidak hanya membentuk manusia Indonesia yang cerdas secara nalar kognitif, tetapi juga harus berkepribadian dan berkarakter. Dengan demikian, diharapkan nantinya akan tercetak generasi bangsa yang tumbuh berkembang dengan karakter yang berlandaskan kepada nilai-nilai bangsa serta agama.

Di sisi lain, Pendidikan Agama yang merupakan bagian dari pendidikan nasional memiliki peranan yang sangat penting dan strategis daalam rangka mewujudkan fungsi dan tujuan pendidikan nasional sesuai amanah di atas. Penegasan tersebut terlihat dalam Peraturan Pemerintah Nomor 55 tahun 2007 tentang Pendidikan Agama dan Pendidikan Keagamaan Pasal 2 ayat (1) yang menyatakan bahwa Pendidikan Agama berfungsi untuk membentuk manusia Indonesia yang beriman dan bertakwa kepada Tuhan Yang Maha Esa serta berakhlak mulia, dan mampu menjaga kedamaian dan kerukunan hubungan intern dan antar umat beragama.

SK Mendiknas No. 232/U/2000 muncul pada 20 Desember tahun 2000 yang menjadi pedoman dalam penyusunan Kurikulum Pendidikan Tinggi dan Penilaian Hasil Belajar Mahasiswa. Dalam Bab 1; Ketentuan Umum, Pasal 1 ayat (7) menyatakan bahwa kelompok matakuliah pengembangan kepribadian (MPK) adalah kelompok bahan kajian dan pelajaran untuk mengembangkan manusia Indonesia yang beriman dan bertakwa kepada Tuhan Yang Maha Esa dan berbudi pekerti luhur, berkepribadian mantap, dan mandiri serta mempunyai rasa tanggung jawab kemasyarakatan dan kebangsaan.

Selanjutnya, Direktur Jenderal Pendidikan Tinggi Departemen Pendidikan Nasional Republik Indonesia dengan SK Nomer 
43/DIKTI/Kep/2006 Tentang Rambu- Rambu Pelaksanaan Kelompok MataKuliah Pengembangan Kepribadian di Perguruan Tinggi menetapkan bahwa Pasal 1 "Visi Kelompok Matakuliah Pengembangan Kepribadian ( MPK) di perguruan tinggi merupakan sumber nilai dan pedoman dalam pengembangan dan penyelenggaraan program studi guna mengantarkan mahasiswa memantapkan kepribadiannya sebagai manusia Indonesia seutuhnya ".

Pasal 2 menyatakan bahwa "Misi Kelompok Matakuliah Pengembangan Kepribadian (MPK) di perguruan tinggi membantu mahasiswa memantapkan kepribadiannya agar secara konsisten mampu mewujudkan nilai-nilai dasar keagamaan dan kebudayaan, rasa kebangsaan dan cinta tanah air sepanjang hayat dalam menguasai, menerapkan dan mengembangkan ilmu pengetahuan, teknologi dan seni yang dimilikinya dengan rasa tanggung jawab".

Adapun Kompetensi Kelompok Matakuliah Pengembangan Kepribadian dicantumkan dalam Pasal 3 ayat (1) sebagai berikut: "Standar Kompetensi kelompok MPK yang wajib dikuasai mahasiswa meliputi pengetahuan tentang nilai-nilai agama, budaya, dan kewarganegaraan dan mampu menerapkan nilai-nilai tersebut dalam kehidupan sehari-hari; memiliki kepribadian yang mantap; berpikir kritis; bersikap rasional, etis, estetis, dan dinamis; berpandangan luas; dan bersikap demokratis yang berkeadaban.

Secara khusus untuk Kompetensi dasar MPK Pendidikan Agama dicantumkan dalam Pasal 3 ayat (2) sub a yaitu " menjadi ilmuwan dan profesional yang beriman dan bertaqwa terhadap Tuhan Yang Maha Esa, berakhlak mulia, dan memiliki etos kerja, serta menjunjung tinggi nilai-nilai kemanusiaan dan kehidupan".

Melihat rambu-rambu tersebut di atas pada prinsipnya merupakan standarisasi Pendidikan Agama Islam di Perguruan Tinggi Umum. Rambu-rambu tersebut kemudian dikembangkan lebih lanjut oleh Tim Pengembangan Pendidikan Agama Islam di DIKTI, yaitu dengan disusunnya acuan pembelajaran MPK PAI Tahun 2007, yang kemudian dituangkan dalam buku Standar Nasional PAI pada PTU tahun 2010.

Rumusan-rumusan di atas, baik Undang-undang, Peraturan Pemerintah maupun Surat Keputusan menunjukkan bahwa Indonesia yang berlandaskan Pancasila bertekad kuat untuk mewujudkan generasi bangsa yang tidak hanya cerdas, cakap dan mampu secara intelektual tetapi juga berkepribadian yang kuat berpedoman kepada nilai-nilai agama dan bangsa dalam menjalankan kehidupan berbangsa dan bermasyarakat. Untuk mencapai pribadi yang cerdas dan berkarakter unggul tentunya memerlukan sebuah sistem pendidikan 
yang baik dan inilah salah satu alasan Pendidikan Agama Islam harus dilaksanakan dengan optimal.

Dalam Islam antara pembentukan karakter dengan pendidikan tidak bisa dipisahkan begitu saja. Setiap disiplin ilmu dalam Islam selalu melibatkan etika keagamaan. Pentingnya akal dan wahyu dalam menentukan nilai-nilai moral selalu terbuka untuk didiskusikan. Islam menengahkan tiga nilai utama yaitu akhlak, adab, dan keteladanan. Akhlak merujuk pada tugas dan tanggung jawab manusia selain syariah dan ajaran Islam secara umum. Adab meliputi semua sikap yang dihubungkan dengan tingkah laku yang baik. Sedangkan keteladanan adalah kualitas karakter yang ditampilkan seorang muslim yang baik dengan mengikuti teladan dari Nabi Muhammad SAW. Inilah tiga nilai yang menjadi pilar pendidikan karakter dalam Islam.

Pendidikan karakter sejatinya adalah bukan sekedar hubungan horizontal antara individu dengan individu lain, tetapi juga antara individu yang memiliki hubungan vertikal dengan Tuhan yang diimani. Oleh karena itu, integrasi antara pendidikan agama, dalam hal ini pendidikan agama Islam dengan pendidikan karakter (pembentukan karakter) mutlak diperlukan dalam usaha mewujudkan tujuan pendidikan nasional bangsa yang berdasarkan kepada Pancasila.

\section{METODE PENELITIAN}

Penelitian ini adalah penelitian kualitatif yang mengambil lokasi penelitian di lingkungan Sekolah Tinggi Ilmu Ekonomi Indonesia Surabaya yang terletak di Jalan Menur Pumpungan No. 30 Surabaya. Adapun subyek penelitian ini adalah para dosen Mata Kuliah Pengembangan Kepribadian Pendidikan Agama Islam di STIESIA dan para mahasiswa STIESIA yang sudah mengikuti MPK PAI. Data dalam penelitian ini, baik primer maupun sekunder dikumpulkan dengan teknik wawancara, observasi, dokumentasi dan triangulasi. Data-data tersebut kemudian dianalisis menggunakan model analisis Spradley dengan empat tahapan yaitu analisis domain, analisis taksonomi, analisis komponensial, dan analisis tema kultural. ${ }^{9}$

\section{HASIL DAN PEMBAHASAN}

\section{1) MPK PAI di STIESIA}

Pendidikan Agama Islam di STIESIA dimasukkan dalam kelompok mata kuliah pengembangan kepribadian ( MPK) sesuai dengan SK DIKTI Nomer 43 Tahun 2006. Pendidikan Agama Islam dideskripsikan sebagai mata kuliah yang membahas tentang kedudukan, tujuan, dan

\footnotetext{
9 Sugiyono, Metode Penelitian Pendidikan, Pendekatan Kuantitatif, Kualitatif, dan R\&D, (Bandung: Alfabeta, 2015), Hlm. 349-356.
} 
proses pembelajaran MPK PAI, pengertian agama, perlunya manusia terhadap agama, sejarah pemikiran manusia tentang Tuhan. Di samping itu, arus globalisasi yang semakin deras telah menghilangkan batas-batas geografis, dalam mengimplementasikan iman dan taqwa, umat Islam banyak menghadapi problem dan tantangan. Maka pembahasan tentang hukum, HAM dan demokrasi dalam Islam. Etika, moral akhlak sangat dibutuhkan. Masyarakat Indonesia adalah masyarakat yang pluralistik, majemuk dan heterogen. Oleh karena itu, perlu mengamalkan Islam yang Rahmatan Lil 'alamin supaya terwujud masyarakat madani yang dilandasi oleh ukhuwah Islamiyyah guna mewujudkan kerukunan antar umat beragama.

Capaian Mata Kuliah yang ingin dituju dalam perkuliahan Pendidikan Agama Islam adalah " mahasiswa diharapkan mampu menganalisis rukun iman dan pengertian agama serta perlunya manusia terhadap agama. Terampil menguasai IPTEK untuk disinergikan dengan IMTAK (Iman dan Taqwa) secara mandiri dan bertanggungjawab".

Adapun Learning Outcome yang diinginkan setelah memenuhi tujuan pembelajaran mata kuliah Pendidikan Agama Islam ini meliputi 3 hal yaitu :

1. Kemampuan Keterampilan

a) Mahasiswa mampu memahami kedudukan, tujuan, dan proses pembelajaran MPK PAI, pengertian agama, perlunya manusia terhadap agama, sejarah pemikiran manusia tentang agama

b) Mahasiswa mampu mempresentasikan informasi dan mengemukakan ide dengan jelas, baik secara lisan maupun tertulis, kepada pemangku kepentingan

c) Mahasiswa mampu memanfaatkan IPTEK untuk menyelesaikan permasalahan serta mensinergikan dengan IMTAK, guna mewujudkan kerukunan antar umat beragama demi mewujudkan masyarakat madani yang berperadaban tinggi

d) Mahasiswa mampu berkontribusi dalam tim untuk menyusun, menganalisis, dan menginterpretasi laporan, hakekat manusia sebagai khalifah di muka bumi beserta peran dan tanggung jawabnya

e) Mahasiswa mampu memilih dan mengembangkan solusi yang tepat dan benar menurut hukum, HAM dan demokrasi dalam Islam 
f) Mahasiswa mampu mengambil keputusan strategis dan memberi saran kepada orang lain terkait dengan Ekonomi Islam berdasarkan etika, moral dan akhlak terpuji

g) Mahasiswa mampu melaksanakan manajemen zakat dengan baik, sehingga mampu merubah mustahiq menjadi muzakki.

h) Mahasiswa mampu memasukkan nilai-nilai Islam dalam kebudayaan Indonesia

2. Penguasaan Pengetahuan

a) Mahasiswa menguasai konsep tentang MPK PAI, Pendidikan Agama dan perlunya manusia terhadap agama, serta menguasai sejarah pemikiran manusia tentang Tuhan

b) Mahasiswa mampu menjelaskan tentang iman dan taqwa serta ciri-ciri orang beriman dan bertaqwa

c) Mahasiswa mampu menjelaskan kerangka konseptual tentang hakikat manusia, peran dan tanggungjawabnya sebagai khalifah di muka bumi

d) Mahasiswa mampu menjelaskan hukum, HAM dan demokrasi dalam Islam serta kontribusi hukum Islam dalam perumusan hukum nasional

e) Mahasiswa mampu memecahkan berbagai masalah agama dengan cara yang rasional

f) Mahasiswa mampu memberi kontribusi untuk memperbaiki untuk memperbaiki praktik kerukunan antar umat beragama dalam masyarakat yang majemuk

g) Mahasiswa mampu memngidentifikasi masalah yang terdapat di masyarakat yang dapat diangkat menjadi topik penelitian

h) Mahasiswa mampu memberi sumbangan dan gagasan pemikiran dalam rangka pengembangan etika moral dan akhlak terpuji di Indonesia

3. Kemampuan Sikap

a) Mahasiswa mampu berkontribusi dalam peningkatan mutu kehidupan bermasyarakat, berbangsa, bernegara, dan peradaban berdasarkan Pancasila

b) Mahasiswa mampu bertanggungjawab atas pekerjaan di bidang keahliannya secara mandiri

c) Mahasiswa mampu mengambil keputusan yang tepat dalam melakukan supervisi dan evaluasi terhadap pekerjaan yang menjadi tanggungjawabnya

d) Mahasiswa memiliki kemampuan bekerja secara tim, berdedikasi, dan toleran dalam pengembangan praktik 
agama Islam berdasar akhlak mulia yang sesuai dengan lingkungan.

Dari penjabaran di atas terlihat bahwa selain kecerdasan intelektual dalam memahami konsep-konsep Agama Islam, kecerdasan emosional dan karakter juga dibina agar mahasiswa bisa tumbuh berkembang bersama menjadi generasi yang tidak hanya sekedar paham tentang ajaran agama Islam tetapi juga mampu menjalankan, mengamalkan, dan mensinergikan ipteks dan iman taqwa dalam kehidupan sehari-hari baik sebagai anggota masyarakat, pekerja profesional, maupun peran apa saja yang akan diembannya kelak.

Mata kuliah Pendidikan Agama Islam ditempuh dengan 3 SKS selama 14 kali pertemuan ( tatap muka ). Bukanlah tugas yang mudah untuk mencapai kompetensi yang disebutkan diatas dengan keterbatasan alokasi sks yang sedemikian kecil. Adapun organisasi mata kuliah nya disamakan dengan keputusan DIKTI dengan sedikit pengembangan.

Dari semua dosen Pendidikan Agama Islam yang penulis wawancarai ; dosen MPK PAI di STIESIA tergabung dalam sebuah tim beranggotakan 5 orang dengan satu orang sebagai dosen koordinator ; menyatakan memakai strategi pembelajaran dengan metode ceramah dan diiskusi (tanya jawab), diskusi kelas dan diskusi kelompok (praktek penyelesaian kasus-kasus yang terjadi di masyarakat) dan penugasan (presentasi dan pembuatan makalah). Pendekatan yang diterapkan berbeda-beda karena perbedaan gaya dan karakter yang dimiliki setiap dosen.

\section{2) Tahap Membangun Karakter Mahasiswa STIESIA}

Dari hasil wawancara dengan para dosen Pendidikan Agama Islam di STIESIA, Penulis mendapatkan ada 3 strategi yang dilakukan dalam upaya membangun dan membentuk mahasiswa agar memiliki karakter / akhlak mulia yaitu:

1. Moral Knowing / Learning to know

Tahapan ini merupakan tahapan pertama dalam membangun sebuah karakter yang baik. Orientasi dalam tahapan ini adalah pada penguasaan pengetahuan tentang nilai-nilai. Mahasiswa harus mampu membedakan nilai-nilai akhlak mulia dan akhlak tercela serta nilai-nilai universal; mahasiswa harus mampu memahami secara logis dan rasional ( bukan secara dogmatis dan doktriner seperti selama ini dipraktekkan) tentang pentingnya akhlak mulia dan bahaya akhlak tercela dalam kehidupan; mahasiswa mengenal Nabi Muhammad SAW sebagai figur teladan akhlak mulia melalui 
hadits-hadits dan sunnahnya beserta riwayat-riwayat sejarah perjalanan hidup nabi.

Nilai-nilai di atas selalu ditekankan dalam setiap materi pembelajaran yang disampaikan.

2. Moral Loving / Moral Feeling

Setelah akal, rasio, dan logika pada tahapan pertama ( Moral Knowing), maka sasaran yang akan dituju pada tahapan ini adalah hati, emosi dan jiwa mahasiswa agar mencintai dan membutuhkan nilai-nilai akhlak mulia. Emosi mahasiswa disentuh agar muncul keesadaran, keinginan daan kebutuhann sehingga dapat berujar keepada dirinya sendiri "Iya, saya harus seperti itu...." atau "Saya perlu mempraktekkan akhlak itu..."

Dosen melakukannya dengan cara menceritakan kisah-kisah yang menyentuh hati, kisah perjalanan hidup nabi Muhammad SAWdan para sahabat, ulama' serta tokoh-tokoh dunia yang menjadi panutan dalam berakhlak mulia dan lain sebagainya.

3. Moral Doing / Learning to do

Tahapan ini adalah tahapan puncak yang dikatakan sebagai tanda keberhasilan dalam membangun karakter mahasiswa yaitu mempraktikkannya dalam kehidupan sehari hari. Tujuannya mahasiswa menjadi semakin sopan, ramah, jujur, hormat, penyayang, disiplin, cinta, kasih, adil, murah hati, bertanggungjawab dan seterusnya. Tahapan ini memang diakui sebagai tahapan yang paling sulit dicapai dikarenakan berbagai kendala, seperti alokasi waktu yang diberikan (3 sks), sulitnya mengontrol kegiatan mahasiswa di luar jam perkuliahan dan lain lain. Akan tetapi, yang bisa dilakukan oleh para dosen adalah memberikan contoh keteladanan nilai-nilai akhlak mulia tersebut. Datang tepat waktu bahkan lebih awal dari waktu perkuliahan, menyapa mahasiswa dengan ramah, memberikan nilai yang jujur dan adil, terbuka terhadap kritik dan saran dari mahasiswa, mengajar dengan hati merupakan hal-hal yang selalu dilakukan oleh para dosen Pendidikan Agama Islam.

Pemberian penilaian dilakukan oleh dosen Pendidikan Agama Islam dengan penilaian yang komprehensif dan berkesinambungan. Penilaian mulai dilaksanakan pada awaal proses perrkuliahan sampai akhir perkuliahan. Penilaian ini tidak dilakukan hanya dengan melihat satu aspek saja tetapi semua aspek penilaian yaitu kognitif, afektif, dan psikomotorik.

Penilaian dari awal proses perkuliahan sampai akhir perkuliahan dilakukan dengan memperhatikan sikap serta prilaku mahasiswa di dalam ruang kuliah, yaitu ketika mereka memperhatikan penjelasan 
dosen, ketika bertanya dan mennyampaikan pendapat mereka dalam diiskusi, tingkat keseriusan dan kedisiplinan dalam mengikuti perkuliahan dengan indikator ketepatan waktu datang di kelas dan ketertiban. Cara bertutur kata, cara bertingkah laku, cara berpakaian dan penampilan mahasiswa ketika kuliah juga dimasukkan sebagai pertimbangan dalam memberikan penilaian. Presensi kehadiran mahasiswa, kedisiplinan dalam menyelesaikan semua tugas yang diberikan (pembuatan makalah, presentasi, memimpin doa, membaca alQuran). Semua hal yang disebutkan di atas merupakan aspek-aspek yang diperhatikan dosen didalam memberikan penilaian mengenai karakter mahasiswa. Haasil penilaian karakter sepeti ini menjadi hal yang penting dalam menentukan nilai akhir mahasiswa dalam mata kuliah Pendidikan Agama Islam bersama dengan nilai hasil ujian semester.

\section{3) Efektivitas MPK PAI dalam Pembangunan Karakter Mahasiswa STIESIA}

Dalam penelitian ini, yang dimaksudkan sebagai efektivitas adalah tingkat keberhasilan pembelajaran MPK PAI dalam membangun karakter mahasiswa STIESIA yang diperoleh dengan melakukan wawancara dan observasi dosen selama masa perkuliahan.

Tujuan akhir dari pembelajaran Pendidikan Agama Islam di STIESIA menurut Drs. H. Kasrowi Ahmad, M.H.I. pada hakekatnya tidak hanya para mahasiswa mampu mengikuti perrkuliahan Pendidikan Agama Islam dengan baik dan medapatkan nilai bagus, akan tetapi lebih dipentingkan bahwa pembelajaran Pendidikan Agama Islam dapat mengantarkan mahasiswa memiliki pengetahuan agama yang cukup dan dapat mengamalkannya dalam kehidupan sehari hari. Lebih dikhususkan untuk alumni STIESIA adalah menjadi seorang ahli ekonomi yang berakhlak mulia, yaitu mengamalkan ajaran-ajaran agama Islam baik dari segi aqidah, syari'ah dan akhlak.

Semua mahasiswa yang penulis wawancarai (20 orang) mengatakan "iya" saat ditanya apakah topik pembahasan atau koompetensi-kompetensi yaang ada dalam mata kuliah pengembangan kepribadian Pendidikan Agama Islam membantu mereka membangun karakter atau akhlak mulia. Menurut mereka, Pendidikan Agama Islam sangat berperan penting dalam memfilter pikiran, sikap dan prilaku mereka dalam menghadapi tantangan global dunia sekarang. Agama menunjukkan mereka mana sikap yang benar yang harus dilakukan dan mana yang tidak boleh dilakukan. Semakin meyakinkan mereka bahwa ajaran Islam adalah ajaran yang membuat mereka bisa berperilaku sesuai dengan teladan nabi Muhammad SAW. 
Hal ini tidak terlepas dari kesepakatan para dosen PAI untuk membuat setiap materi Pendidikan Agama Islam bermuatan akhlak mulia. Karena disamping PAI merupakan kelompok mata kuliah pengembangan kepribadian yang mempunyai misi untuk memantapkan kepribadian dan karakter mahasiswa agar terus konsisten mewujudkan nilai-nilai dasar agama dan budaya dalam berpikir, merasa, bersikap, dan berperilaku dalam kehidupan berbangsa dan bermasyarakat, Islam juga menunjukkan bahwa akhlak mulia merupakan buah dari ilmu. Oleh sebab itu, dosen Pendidikan Agama Islam selalu menyelipkan pesan-pesan moral dan akhlak mulia dalam setiap pertemuan dan dalam setiap materi ajar yang disampaikan.

Dari pengamatan selama perkuliahan berlangsung terlihat perubahan sikap yang signifikan dari mahasiswa. Penulis, misalnya, melihat di awal perkuliahan mahasiswa tidak terlalu antusias untuk mengkaji ajaran-ajaran Islam karena menurut mereka agama tidak terlalu memberikan pengaruh besar dalam membantu mereka mencapai nilai-nilai akademik profesional mereka ( = ekonomi ), namun sesudah memperoleh motivasi dan internalisasi nilai meelalui kaajian-kajian maateri yang lebih menndalam, mahasiswa mulai bertambah antusias.

Pengamatan yang sama juga disampaikan oleh Abdus Salam, M. Pd.I. dan Amrozi, M. Fil.I. Beliau berdua mengatakan setelah melalui beberapa kali perkuliahan mahasiswa bertambah antusias untuk mempelajari dan memahami lebih baik mengenai ajaran agama Islam dan pada akhirnya meyakini bahwa Islam adalah solusi dalam hidup. Pandangan mahasiswa terhadap agama berubah dari sekedar ajaran doktriner menuju pandangan bahwa agama adalah suatu kebutuhan untuk hidup lebih efisien dan bahagia.

Contoh lain diajukan oleh Dra. Sholikhah Rosdiana, M.H.I. adalah dalam hal berbusana, terlebih untuk para mahasiswi, seringkali tampak perrubahan yang baik. Pada aawal masuk kuliah, mahasiswii banyak yang belum menggunakan busana muslimah, namun menjelang akhir perkuliahan hampir semua (90\%) menggunakan busana muslimah.

Wawancara dengan 20 orang mahasiswa, menyatakan bahwa setelah mengikuti mata kuliah Pendidikan Agama Islam, mereka lebih termotivasi untuk menjadi pribadi yang lebih baik dari sebelumnya. Penulis merangkum sikap dan prilaku mahasiswa yang mengalami peningkatan dari sebelumnya sebagai berikut :

1. Meningkatnya rasa ketergantungan terhadap Allah dengan melakukan kegiatan-kegiatan ibadah ritual lebih khusyu' 
2. Rasa kepedulian terhadap sesama manusia dengan sikap lebih empati, menolong, dan saling menasehati dalam kebaikan muncul dan bahkan meningkat

3. Meningkatnya rasa kemanusiaan yang diwujudkan dalam sikap gemar membantu orang lain yang sedang dalam kesulitan dan bencana

4. Tumbuh rasa toleransi yang tinggi terhadap orang yang berbeda keyakinan yang diwujudkan dalam sikap lebih menghargai dan menghormati perbedaan yang ada

5. Semakin mencintai Nabi Muhammad SAW dan termotivasi untuk selalu meneladani sikap dan prilaku Nabi dalam kehidupan sehari-hari

Dalam upaya membangun dan membentuk karakter mulia pada mahasiswa STIESIA, penulis mendapatkan ada beberapa hal yang menjadi kendala dan hambatan, yaitu :

1. Keterbatasan alokasi waktu pembelajaran yang berjumlah 3 sks ( 150 menit ). Menyampaikan begitu banyak materi ajar yang telah ditentukan ditambah dengan penanaman nilai nilai akhlak mulia adalah suatu tugas yang berat dan tidak cukup hanya dengan melakukannya selama 150 menit dalam setiap minggu. Tidak bisa dipungkiri bahwa Pendidikan Agama Islam tidak bisa berdiri sendiri tanpa bantuan dari mata kuliah lain terutama yang masuk dalam kelompok mata kuliah pengembangan kepribadian seperti Pancasila dan Kewarganegaraan, dan Bahasa Indonesia. Kerjasama yang baik antara para dosen MPK dan juga dosendosen mata kuliah yang lain mutlak diperlukan demi kesinambungan pembangunan karakter. Begitu juga dengan pihak kampus yang juga harus secara aktif mendukung upaya pembangunan karakter ini sehingga akhlak mulia tidak hanya menjadi materi ajar saja tetapi juga menjadi kultur mahasiswa.

UKKI adalah unit kegiatan kampus yang menaungi kegiatankegiatan keagamaan Islam di STIESIA. Diharapkan dengan adanya UKKI ini karakter mahasiswa lebih terbina. Kegiatan-kegiatan rutin yang dilakukan adalah pengajian, memperingati hari-hari besar Islam seperti maulid, mengadakan kegaiatan-kegiatan sosial kemanusiaan

2. Heterogenitas kemampuan dasar mahasiswa STIESIA dalam pemahaman agama. Latar belakang mahasiswa yang dari umum (non agama, bukan pondok pesantren atau sekolah-sekolah Islam) membuat dosen harus lebih ekstra memberikan pemahaman dasar - dasar keagamaan yang biasanya menyita waktu perkuliahan. Sehingga tujuan yang seharusnya sampai ke 
ranah afektif dan psikomotorik harus terhenti pada ranah kognitif. Dan ini membuat kesan agama Islam yang dalam hal ini akhlak Islam menjadi doktriner ( = salah dan benar )

3. Materi pembelajaran Pendidikan Agama Islam yang lebih banyak menekankan pada ranah kognitif; ini berhubungan dengan kendala yang pertama dan kedua di atas

4. Kurangnya perhatian mahasiswa terhadap masalah akhlak atau pentingnya berakhlak mulia. ini bisa dimaklumi karena tantangan zaman yang dihadapi oleh mahasiswa sekarang sudah sangat kompleks. Arus globalisasi yang memutus sekat-sekat geografis membuat informasi dan penyebaran pola pikir dan pola hidup ( sikap dan prilaku ) manusia ditambah dengan tumbuh pesatnya teknologi menjadi bumerang bagi mahasiswa sendiri jika tidak cerdas dan bijak dalam memaknainya.

5. Kontrol terhadap mahasiswa di luar jam perkuliahan yang sulit membuat pembiasaan karakter menjadi terputus. Penulis mencoba mengatasi kendala ini dengan menugaskan mahasiswa untuk mengisi lembaran muhasabah diri dan hasilnya bisa dikatakan kurang maksimal.

Kendala-kendala di atas berusaha diantisipasi oleh para dosen Pendidikan Agama Islam dengan selalu melakukan evaluasi ulang setiap semester. Terbukti dengan adanya rapat pleno yang diadakan oleh pihak kampus STIESIA setiap semester yang mempertemuksn para dosen MPK PAI untuk koordinasi dan diskusi mengenai pembelajaran Pendidikan Agama Islam lebih baik ke depannya.

\section{E. PENUTUP}

Berdasarkan hasil peneletian dan pembahasan yang diajukan dalam penelitian ini, maka bisa disimpulkan sebagai berikut : pertama, Pendidikan Agama Islam berhubungan erat dengan pembangunan karakter. Ini terlihat dari tujuan umum dari pendidikan dalam Islam adalah menciptakan manusia yang cerdas secara intelektual dan berkhlak mulia. Kedua, Pembangunan karakter melalui mata kuliah Pendidikan Agama Islam di STIESIA ditempuh dengan 3 strategi yaitu : (1) Moral Knowing/ Leraning to Know, merupakan tahap pertama yang dilakukan para dosen Pendidikan Agama Islam dan berorientasi kepada penguasaan pengetahuan tentang nilai nilai akhlak mulia; (2) Moral Loving / Moral Feeling, tahapan dimana setelah mahasiswa mampu menguasai pengetahuan tentang nilai-nilai akhlak mulia, dosen menyentuh aspek emosional jiwa dan hati mahasiswa agar mencintai nilai-nilai akhlak mulia tersebut dan "butuh" untuk melakukannya dalam kehidupan sehari-hari; dan selanjutnya (3) Moral Doing / Learning to do, adalah tahapan puncak 
yang dikatakan sebagai tanda keberhasilan dalam membangun karakter mahasiswa yaitu mempraktikkan akhlak mulia dalam kehidupan nyata sehari-hari. Ketiga, Mata kuliah Pendidikan agama Islam di STIESIA berhasil membangun karakter mahasiswa menjadi lebih baik. Ini terlihat dari pengamatan yang dilakukan oleh para dosen Pendidikan Agama Islam maupun wawancara penulis dengan mahasiswa STIESIA yang sudah menempuh mata kuliah Pendidikan Agama Islam.

\section{DAFTAR PUSTAKA}

Dirjen Pendidikan Tinggi Kemendiknas. 2010. Kerangka Acuan Pendidikan Karakter.

Kesuma, Dharma et al. 2013. Pendidikan Karakter, Kajian Teori dan Praktik di Sekolah. (Bandung: PT. Remaja Rosdakarya).

Majid, Abdul dan Dian Andayani. 2017. Pendidikan Karakter Perspektif Islam. (Bandung: PT. Remaja Rosdakarya).

Peraturan Pemerintah No. 19 tahun 2005 tentang Standar Nasional Pendidikan.

Permendiknas No. 22 tahun 2006. Tentang Standar Isi Untuk Satuan Pendidikan Tingkat Dasar dan Menengah.

Sugiyono, 2015. Metode Penelitian Pendidikan, Pendekatan Kuantitatif, Kualititaif, dan $R \& D$. (Bandung : Alfabeta).

Surat Keputusan Mendiknas No. 232 / U/2000 tentang Pedoman Penyusunan Kurikulum Pendidikan Tinggi dan Penilaian Hasil Belajar Mahasiswa

Surat Keputusan DIKTI No. 43 /DIKTI/Kep./2006 tentang Rambu-Rambu Pelaksanaan Kelompok Matakuliah Pengembangan Kepribadian di Perguruan Tinggi

Undang-Undang No. 20 tahun 2003 tentang Sistem Pendidikan Nasional 